\title{
Primary school teachers' and students' perception of values and media literacy
}

\author{
Paula Renes-Arellano, Sara Barral-Aramburu \\ Faculty of Education at the University of Cantabria, Spain \\ corresponding e-mail: paula.renes@unican.es \\ postal address: Avenida Los Castros, s/n Santander, Cantabria, Spain
}

\begin{abstract}
Ephemeral changes, cultural diversity, globalization processes, the media and the crisis of values in modern society require a profound reflection on the role of education and teachers in the integral formation of students. This paper has the purpose of knowing the perception and experience of teachers and students in the field of media based literacy and education in values. The methods of investigation used were qualitative, by using techniques such as the daily observation logs and the interview; and quantitative and qualitative, with the design, development and implementation of a questionnaire. The results show that teacher and students training on a value-based education and on media-based literacy is needed. Such training could be considered as an educational initiative to incorporate into the main school project.
\end{abstract}

Keywords: Primary school, values education, childhood, media literacy, student's view, teacher's view.

Citation: Renes-Arellano P., Barral-Aramburu S., 2016 "Primary school teachers' and students' perception of values and media literacy", Applied Technologies and Innovations, Vol.12(2), pp.80-94, http://dx.doi.org/10.15208/ati.2016.07

\section{Introduction}

Nowadays, there are big and different tensions generated by "technological, economic and social change. They included tensions between the global and the local; the universal and the particular; tradition and modernity; the spiritual and the material; long term and short term considerations; the need for competition and the ideal of equality of opportunity; and the expansion of knowledge and our capacity to assimilate it." (UNESCO, 2015, p.20). This situations represent the current dynamic that frame the social transformations and their relevance regarding the social structure and the cultural patterns of each society.

The culture that defines people can only be understood from the global comprehension of the knowledge, laws, moral art and other capabilities acquired by each person in a given society (Giner, 1996, as quoted in Lázaro and Palomera, 2004)

Values as well as norms, instruments, language and signs are understood as essential elements of each culture.

This work is supported by the $\mathrm{R}+\mathrm{D}+\mathrm{I}$ Project entitled "Media competences of citizens in emerging digital media (smartphones and tablets): Innovative practices and educational strategies in multiple contexts", EDU2015-64015-C3-1-R (MINECO / FEDER), financed by the European Regional Development Fund (ERDF) and Ministry of Economy and Competitiveness of Spain. 
Independently from the cultural diversity and, therefore, the values and habits of each group of people, as claimed by Martínez Martín, Puig and Trilla (2003), each individual faces experiences morally controverted and daily solves conflicts of value. "Thus, in an attempt to find solutions to the individual and collective conflicts, people not only use their individual abilities but also value guides that allow them to orientate the settlement of conflicts" (Martínez Martín, Puig and Trilla, 2003, p.72). The evident moral values of a society are materialized in ideas about the world, models, practices, institutions and other components that help, in turn, as a feedback of values guides for current and future citizens.

From this view, inside the educational institution, which is a part of every human community, the ultimate goal should be to help learners to build their own values through intellect, so that in this way, they are able to integrate as social beings in the world that they have to live in (López, Carpintero, Del Campo, Lázaro and Soriano, 2006).

As many experts pointed out, some decades ago, the main socialization media to build the social bases of the learner were the family, the school and the peer group. Nowadays, even though they still have an essential role, communication media, mainly, television, the cinema and Internet share the task of forming an individual. It is usual that children are in constant contact with audio-visual media, which can enhance their influence in their first years of life (Jiménez, 1997; Carr, 2011; Martín and Tyner, 2012; Cuervo, Medrano and Aierbe, 2016).

In this regard, the influence of communication media over culture, lifestyle, and behaviour and, above all, the values formation of people is evident and increasingly accused. This new circumstance is accompanied by a strong and growingaudio-visual culture that impregnates our context and that has to be taught in schools in a reflexive manner through the critical analysis of the media event, avoiding the aggravation of interpretation, understanding and illiteracy problems that are present in contemporary societies (Ambrós and Breu, 2007; García Ruíz, Ramírez and Rodríguez , 2014).

\section{Crisis of values in our society: citizens in constant movement}

As Buxarris explains (1997), in global societies that are contemporary, heterogeneous and with ephemeral changes, it is valid to ask why to educate in values. Undoubtedly,our society is undergoing a "values crisis. It is normal to read in the media news about armed conflicts, sexual abuses, mistreatment, child delinquency, human rights violations, racism, etc. In this regard, it is worth asking which is the cause of these events and which is the role of education. It is normal, mainly in communication media, to blame the educational system and specifically, teachers and schools, for the social problems that arise.

In Mínguez Vallejos (2014) words:

There is a deep division of criteria and fundamental references of social coexistence, of which the most evident manifestation is the situation of fragility in which the interpersonal relations are immersed. This situation is not another crisis, but, in its roots, it is a crisis regarding the lifestyle of human beings at the beginning of this century. It would be cautious to think that this does not have serious implications in the educative field, specially supposing that our vital time and space demand from themselves new reformulations. (p.211)

Technological and scientific progress cause new ethic matters to arise, which are difficult to resolve. In societies, there are relevant problems that do not have a unique, accurate and ideal solution but they are situations in which the ethical dimension orients the behaviour towards those conflicts (Albizuri, Samaniego and Torrientes, 2001).

In this regard, communication media represent an important socialisation and learning channel that, sometimes, can promote a mental scheme of the world that does not match with those upheld by the academic framework (Martínez Martín, 2011).

Consequently, the growing multiculturalism present in our society is an important educative challenge and, at the same time, an opportunity to move forward to a 
community that opens the tracks for cultural exchange under equal conditions. The role of school in this context is to provide learners with "the keys to build their own autonomous mental frame, a personal, cultural and social identity that covers all the dimensions of their personality, $[\ldots]$ that is useful to freely move and participate in the world that was given to them" (Besalú, 2002, p.111)

In light of the existence of different societies with plurality of ideas and notions to understand and live life, it is unthinkable that there are ultimate models to understand and operate in the world. Human beings face, constantly, values conflicts at a personal level, and depending on the scale of values and understanding of events, decisions are made that, ultimately, affect their relationships with others.

In this sense, it is undisputed the necessity of values-based education in educative centres in order to create cohabitation habits based on democratic values through dialogue and participation of all the students.

For these habits to become part of the academic culture of the centre, this centre should act as a unit, as a system; in other words, it should be "an interrelated and coherent set of practices that succeeds in increasing the educative effect precisely because of the synergy established among all the proposals" that take place there (Martínez Martín, Puig and Trilla, 2003, p.76).

Nevertheless, the educative centre is not the only place where values-based education takes place. It should be, with the family, the main context to learn and train in personal, professional and academic fields. Likewise, the school is one of the places where children spend most of their childhood and, thus, it assumes a central role in attitudes learning such as respect, commitment and solidarity. Therefore, the school is an important force that influences the personality development of the student because, since its origin, it has been a means to transmit ideologies; one of its main duties has been and is the socialization of individuals (Deval, 2002; Martínez Martín, Esteban and Buxarrais, 2011).

In this respect, society trusts that school as well as teachers teach democratic values and pursue the common good. However, what is entrusted to them is not promoted by all its members. Some social agents, even though they do not have an educative mission per se, have a significant influence in building children, youngsters and adults' personalities. Considering this, a values-based education is necessary from the educative institution, not in any manner, but in an articulate, correlated and real way that prioritise the comprehensive training of the student (professional, academic and moral) against a merely formal training, thus defeating traditional tendencies that are not adapted to the contemporary word we live in.

\section{The importance of values-based education in schools}

According to Savater (1997), context is closely related to education. Society influences the school framework and in turn, the performance of the education system influences the community. At school, students must acquire a "cultural volume" that allow them to live peacefully in an environment of ambiguity, uncertainty, different point of views and disagreements and the absence of unfailing and reliable authorities (Halstead and Taylor, 1996).

As a consequence, values are crucial for education and educative practical activities in two ways. On one hand, schools and teachers, along with families, communication media and peers are an important influence regarding the development of values in children and youngsters, and therefore, society in general. On the other hand, schools are the reflection and personification of social values. In fact, they owe their existence to the fact that society values education and intends to influence the development model of its own future by education (Halstead and Taylor, 1996).

That being said, in accordance with Sutrop (2015), many of the decisions we make regarding education depend on what we consider to be its goals. According to the Human 
Autonomy Theory, the goal of education is to increase the individual's freedom, his options and the right of free will. The Human Capital Theory, by contrast, asserts that the goal of education is to provide a guarantee for academic growth: the more the education regarding formal and conceptual work, the higher the productivity. The Human Development Theory considers that it is important to use education as a way to create the right conditions to help students to reach a global development, thus including, their personality development. Finally, the Civic Education Theory affirms that the goal of education is to prepare the individual for their coexistence with others in society.

In the last decades, the Human Capital Theory has prevailed in education (as quoted in Brighouse, 2006). In this way, considering these multiple perceptions, in the present study, it is understood that all the mentioned goals supported by the four theories should be integrated within the educational purposes. Its goal would include enhancing human freedom and the ability to make decisions, teaching strategies and creating proper conditions to interact and socialize with others, preparing people to live together. In the same way, from school it would be necessary to provide security and professional guidance as well as practical and emotional education. Consequently, education covers relevant and broad goals that have a close, complex and articulate relationship.

As sustained by Braslavsky (2004), education is the way in which we adapt to the world around us. It prepares us not only in a conceptual level thanks to a set of social, physical and cultural skills, but also in a personal level. It should prepare people to make conscious and autonomous decisions. It is not limited to the formal development but to the simultaneous and balanced training regarding three matters: the cognitive, the practical and the emotional.

As a consequence, the key pedagogical reasons to uphold a values-based education are: firstly, codification; it allows us to understand and decode what is around us. We learn to write, count, read, etc. Secondly, adaptation; it shows us which conventional and social standards we must understand and fulfil in order to determine how the environment works and how we adapt to it. We are taught to sit properly in class, respect our turn to speak, ask for permission. The third dimension stated by the author is the projective dimension; it is understood as the ability of people to create an organization of the environment according to their own values: the way we dress, the way we arrange our bedroom. We organize our possessions according to personal criteria. Lastly, introjection explains how values allow us to be self-aware. It helps us to adapt to our surroundings and to obey rules established from outside but we also organize the things around us and we are aware that what we think is done by ourselves and our own values ranking. Many analyses about school educational practices show the training deficiency in the school setting regarding these last two matters (Buxarrais and Martínez Martín, 2009).

In this context, the ultimate goal of the educational intervention is to help students to set their own values through reasoning, so that in this way they can merge as social beings into the world they have to live in (López, Carpintero, Del Campo, Lázaro and Soriano, 2006).

\section{Underlying values in light of a new literacy in media}

In this regard, when introducing an innovation or an educational research it would be appropriate to draw from the premise set by the United Nations (2015) in its work "Rethinking Education: Towards a global common good?".

"In revisiting the purpose of education, our vision is guided by a central concern for sustainable human and social development. [...] The changes in today's interconnected and interdependent world are bringing new levels of complexity, tensions and paradoxes, as well as new knowledge horizons that we need to consider. Such patterns of change require efforts to explore alternative approaches to progress and to human wellbeing" (p.20).

In this way, as a result of the scientific and technological evolution that took place in the last years, children and youngsters have grown in an environment where media and 
technology are part of their daily routines (Carr, 2011; Martín and Tyner, 2012). According to Pérez Rodríguez, Delgado, García Ruíz y Caldeiro (2015), the immediate access to them creates generations with a different way of interacting, investing time, living family and school life (as quoted in Bringué and Sádaba, 2009).

Therefore, because of the unstoppable technological development, the omnipresence of media in our lives and the growing concern to define concepts as media competence, competence in media or audio-visual competence (as designated in different contexts) it is more and more necessary a media literacy from a comprehensive, multidimensional, universal, critical, inclusive, flexible, continuous and significant approach that promotes the development of media competence for the digital and technological society (Aguaded, Ferrés, Cruz, Pérez Rodríguez, Sánchez Carrero and Delgado Ponce, 2011; García Ruíz, Ramírez and Rodríguez, 2014; Tyner, Gutiérrez Martín and Torrego, 2015). In consideration of this reality, it is relevant to consider which agents and institutions should take responsibility of a media education: is it a role that belongs to the family? Or, on the contrary, is it necessary to include it in the school curriculum in more depth? Which is the role of the school regarding this education? Which political events would enhance quality media literacy? Hereunder, these and other related matters are considered.

To begin with, this document, in regard to the dimensions of the defended multiple and comprehensive media literacy, would encompass basic skills for the contemporary digital context. These basic skills would be part of a transversal media education that would involve "accessing, analysing, creating, reflecting and acting" with and regarding communication and information media and technologies (Tyner, Gutiérrez Martín and Torrego, 2015, p.48). As a consequence, it is understood that audio-visual, digital, technological or computing skills are closely related and included in the media skill, so all the categories can be identified in the same context for which the knowledge of media and new technologies is required (González Fernández, Sedeño and González Pérez, 2012). Therefore, every time audio-visual education is mentioned, it also makes reference to a media education or skill.

Accordingly, concerning the dimensions of media skills, Ferrés (2007) distinguishes six strands that are constantly interrelated: language, technology, interaction processes, production and dissemination processes, aesthetics and lastly, ideology and values. The latter would correlate with the subject's ability to perform an understanding and critical reading of the audio-visual messages. In other words, the individual would be able to distinguish the underlying interests, values and stereotypes of the messages transmitted by the media. In the same way, we must differentiate reality from its representation offered by the media, knowing the role of new technologies in this context, the factors that cause that messages are products subjected to specific interests, understanding that information comes from different sources and learning to differentiate and identify the emotions that those messages cause in the audience (Pérez Rodríguez, et al., 2015).

In this regard, from the educational institution, an optimal learning environment for media literacy should be granted for students, family and teachers through the inclusion of this perspective in the curriculum, so that educational activities are performed using didactic resources to achieve these goals(Celot and Pérez Tornero, 2009).

With regard to the aforementioned, in daily practices it is not enough to use media without a planned pedagogic purpose. According to experts around the world, the rhetoric reality of this situation involves that teachers acquire certain knowledge and skills in order to successfully include media in their daily dynamic (Tiede and Grafe, 2016).

However, according to Ramírez, Renés y García Ruíz (2014), if studies about media skills in the educational field are analysed, two prevailing matters are observed. On the one hand, the scarcity of the own studies and, on the other hand, the lack of inclusion of media skills in the curricula (as quoted in Tucho, 2008; Camps, 2009; Aparici, Campuzano, Ferres and García, 2010). That skill, is not one of the eight basic skills but it is reflected in the curriculum as transversal goals within the different fields of knowledge. 
In light of the foregoing, the challenge of trying that students become a crticical audience, learning to decode the visual language and thus, neutralising its manipulative effect and using it as an eminently educative resource, is presented (Gómez de Benito, 1996; Pereira Domínguez, 2005).

\section{Method}

Considering the previous theoretical revision, it is the aim of the following empirical study to collect the view of teachers and students of Primary Education about values-based education and its relationship with media education.

To this effect, a qualitative investigation has been conducted, performing a case study using in-depth interviews for the teacher and a close observation collected in a journal. Finally, a questionnaire has been completed (quantitative and qualitative) to collect the students' perception and experiences.

\section{Goals}

The goals that lead the study are the following:

1. Knowing the perception and experience of the teacher and students regarding the media and values-based education.

2. Assessing the educational needs and deficiencies of students and teachers regarding values-based education.

3. Identifying the interests and preferences of students within the framework of communication media.

\section{Sample}

The sample was constituted by one teacher of Primary Education of the Autonomous Community of Cantabria (Spain) and her students (24 learners), constituting an incidental sample.

What inspired the choice of the teacher as a sample was the possibility of comparing data collected by the in-depth interview with the information gathered in the journal during the observation months in the centre. This analysis of the educational reality in the classroom was performed during the months of February, March and April 2016.

The teacher and students voluntarily participated after being informed in a meeting about the goals of the study. Through the participating teacher we had access to the students' sample, analysed in an incidental manner.

\section{Data collection technique}

\section{The observation journal}

An observation journal was used in the study. It is a tool employed as a channel to perform a self and hetero observation, collecting relevant information about people and their environment as a result of the research. It acted as a positive feedback, allowing the researcher to be aware of the actions and thoughts about the daily practice under observation and to know the needs of the sample with which the researcher interacted (Martínez, 2007; Quintana, 2008; Jiménez, 2011). Likewise, by the use of this tool for data collection, the subsequent analysis of the gathered information in the interview and the questionnaire is more complete and better-founded. 


\section{The interview}

Finally, the in-depth interview was chosen, considering it the most suitable qualitative and structured methodological strategy for data collection to understand the perspective and the teaching experience regarding communication media, values-based education and their relationship with the school framework. According to Valles (2002, p.41) the in-depth interview used in this study was semi-structured, thus collecting important elements of daily aspects.

The steps followed to process the information, the perception and the experience of teachers and students regarding communication media and values-based education were the following:

- Organization of the subject considering the analysis dimensions previously listed;

- Choice of the most relevant content considering the categories created;

- Analysis and interpretation of the selected and listed information, addressed to the learners and students, in order to know their perception and experience regarding values-based education and communication media.

\section{The questionnaire}

According to Caldeiro (2014), in this research, the (on-line) questionnaire is understood as an observation instrument that allows to compare and quantify data, asking questions about a specific topic. Likewise, it has been used as a channel to collect quantitative and qualitative data, for their subsequent analysis and compilation in charts and figures.

To this effect, to compare and analyse the information of the questionnaire, a pilot study was conducted to prove the veracity of the tool and to make the proper changes and improvements. Finally, the questionnaire collected open and closed questions.

\section{Procedure}

During the study the following steps have been followed:

1. Contacting the educational centre of Cantabria (Spain) through the management team, informing the goals and possible benefits of the research, in order to count on their involvement.

2. Informing the students about the purpose and value of the research, requesting their voluntary involvement in the study.

3. Informing all participants (teacher and students) that the interviews would be recorded, asking for their consent. Moreover, it was stressed that their involvement was voluntary and confidential.

4. Beginning of the implementation of the study, reporting future improvements of the investigations to the participants and final analysis of the categorised results according to criteria shown in the results.

\section{Results}

\section{Students' perception regarding values and media}

\section{Students' preference regarding home leisure activities}

In order to know the leisure habits of the learners and the influence of media over them, it is necessary to know to which activities students devote more time. Of the selected 
sample, $66.7 \%$ usually played videogames. Likewise, there is a preference for computers and dolls $(33.3 \%)$

Colour pencils, markers and mobile phones are slightly preferred among students. The $100 \%$ of the sample claimed that they rarely play with colour pencils and markers and $66.7 \%$ barely used the mobile phone. Surprisingly, the 100\% affirmed that they sometimes watch television (see Table 1)

TABLE 1. WHAT DO YOU USUALLY PLAY WITH?

\begin{tabular}{lccc}
\hline Home leisure preferences & Rarely & Sometimes & A lot \\
\hline Board games & $50 \%$ & $33,3 \%$ & $16,7 \%$ \\
\hline Computer & $0 \%$ & $66.7 \%$ & $33,3 \%$ \\
\hline Books & $50 \%$ & $50 \%$ & $0 \%$ \\
\hline Television & $0 \%$ & $100 \%$ & $0 \%$ \\
\hline Dolls & $17,7 \%$ & $50 \%$ & $33,3 \%$ \\
\hline Colour pencils and markers & $100 \%$ & $0 \%$ & $0 \%$ \\
\hline Videogames & $16,7 \%$ & $16,7 \%$ & $66,7 \%$ \\
\hline Mobile pone & $66,7 \%$ & $33,3 \%$ & $0 \%$ \\
\hline
\end{tabular}

\section{Family supervision during the media leisure time}

The family presence during the use of media is crucial to learn to decode subliminal messages and their ultimate meaning. Of the selected sample, the 50\% affirmed that they watch movies, series and advertisements with their grandparents. The $16.7 \%$ with their families, another $16.7 \%$ with their siblings and the remaining $16.7 \%$ on their own. (Figure 1)

FIGURE 1. SUPERVISION OVER THE STUDENTS' MEDIA USE

[At home, I watch films, series, and advertisements with...]

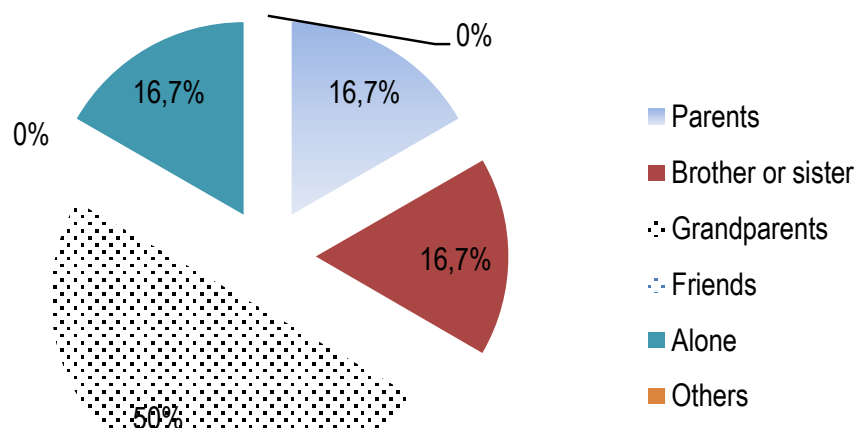




\section{Students' preference regarding leisure activities outside home}

As observed in the figure (Figure 2), during leisure time the $33.3 \%$ of the interviewed learners practiced sports. Another $33.3 \%$ spent their time going to the cinema, against a $16.7 \%$ that preferred going shopping and a $16.7 \%$ going to the park.

\section{FIGURE 2. STUDENTS' LEISURE ACTIVITIES OUTSIDE HOME}

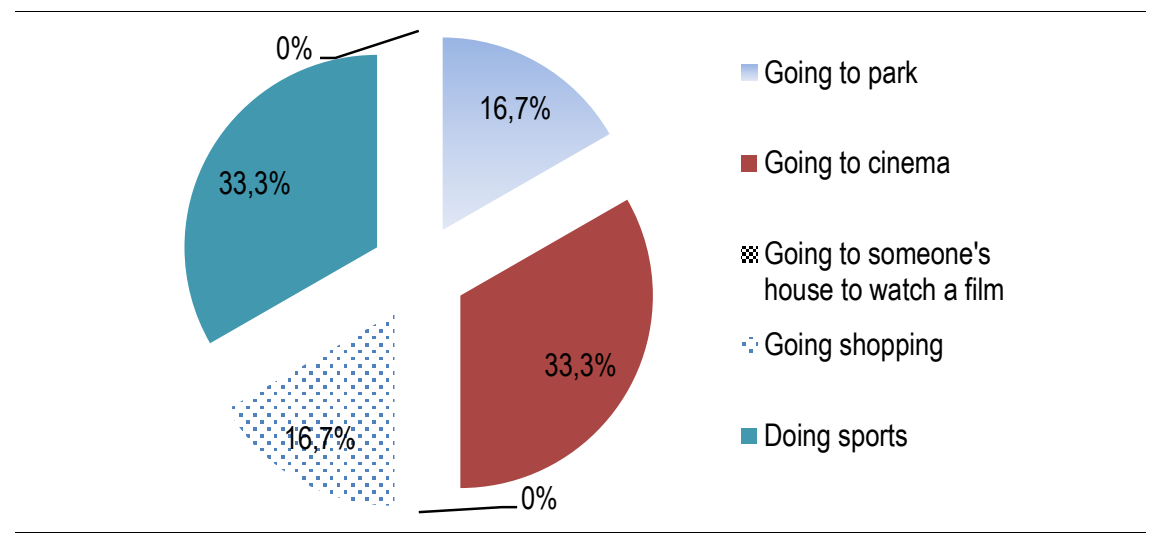

\section{Students' preferred school tools}

To improve education and the achievement of school goals it is necessary to start the learning process considering the interests and motivations of students. As a consequence, in Figure 3, it can be observed that $50 \%$ of the students preferred to use computers in class. Then there is a $33.3 \%$ that preferred cards and the remaining $16.7 \%$ preferred books (Figure 3).

FIGURE 3. STUDENTS' PREFERENCE REGARDING CLASS MATERIAL

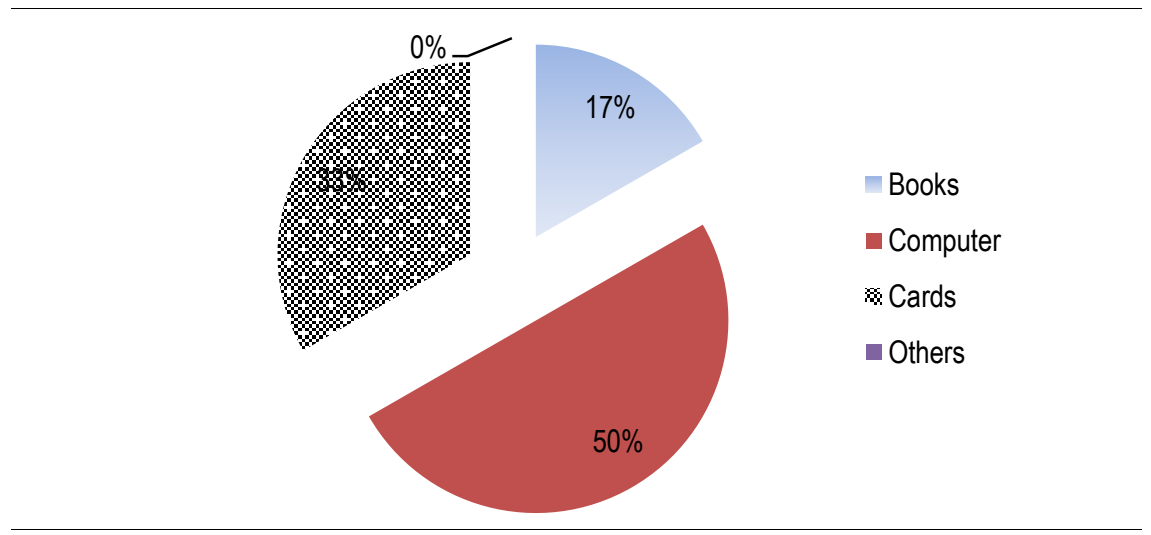


From the $100 \%$ of the selected sample, $83.3 \%$ asserted that they prefer group work in the classroom. In contrast, $16.7 \%$ preferred working on their own. (Figure 4)

FIGURE 4. STUDENTS' WORKING PREFERENCES

[In class, I work better ...]

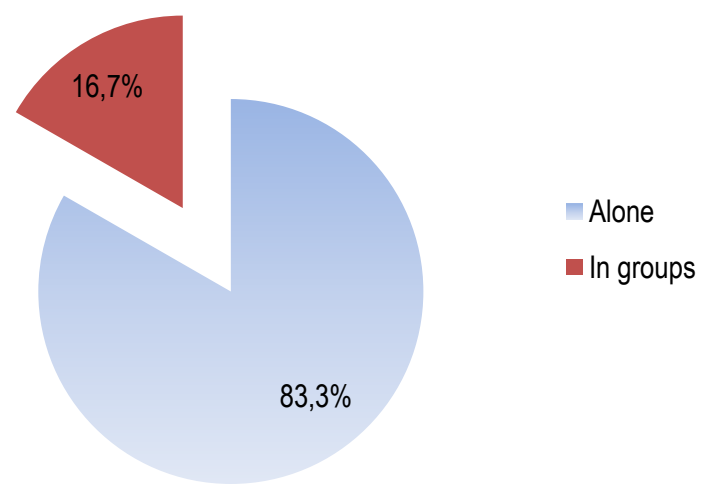

In Figure 5 it is observed that $50 \%$ of the sample chose individual work after finishing compulsory activities in the classroom. The other 50\% preferred to help their classmates finishing the established tasks.

FIGURE 5. STUDENTS' WORK PREFERENCES

[When I finish the class activities, I prefer to ... ]
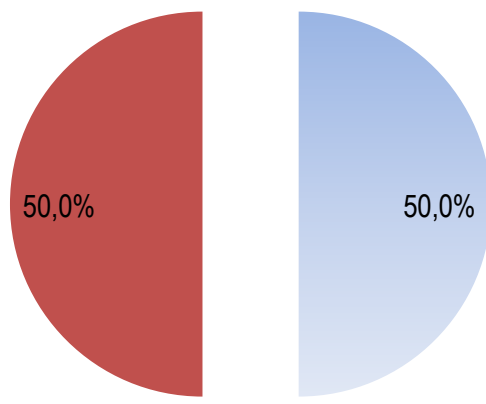
Do worksheets, logical blocks or play with the computer
Help my friends finish their activities


As shown in Figure 6, 88.3\% of the students identify themselves with the value of Love in the short film "Paperman". However, $16.7 \%$ stated that they ignore which values are present, $16.7 \%$ thought that it is cooperation and lastly, the remaining $16.7 \%$ claimed that there is no value present in the short film.

FIGURE 6. IDENTIFICATION OF VALUES IN A SHORT FILM

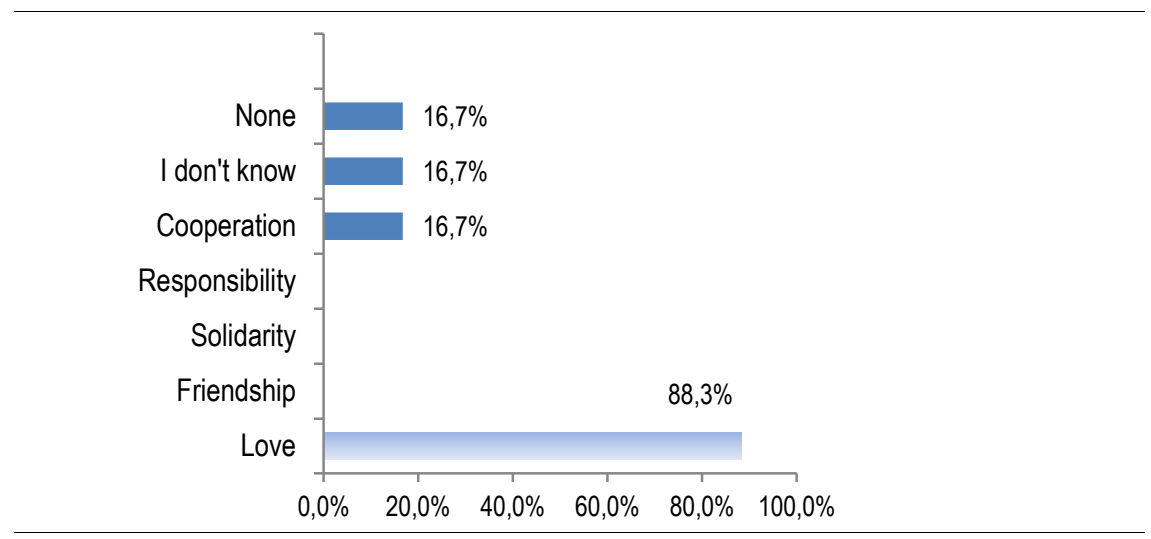

\section{Teachers' perception regarding values and communication media}

\section{Values-based education in the classroom from the teacher's perspective}

The interviewed teacher understands values-based education as a way of educating learners about the importance of a healthy social coexistence. Similarly, she considers school to be an essential socializing cornerstone regarding this mission, since it is the place of coexistence and relation of community members.

"The school is a meeting and cohabitation space between different cultures that are very important in society. We have to raise awareness in children about the importance of selfknowledge and others" (ex.'Teacher 1).

For this matter, considering the historical, cultural and geographical moment in which the teacher is, she considers that there is a crisis of values in contemporary society. Specifically, she expresses her view of the cause of this situation.

"Contemporary society promotes values that are far from being collective, that are centred in the individual, where immediate consumption and individual satisfaction prevail" (ex. Teacher 2).

Then, the teacher expresses her opinion regarding the biggest problem when teaching values at school: the lack of them in society.

About the teachers' training regarding values-based education, she claims that during her childhood at school, the main procedure by which it was achieved was Religion. Religion has implicit crucial values that are desirable for a proper coexistence in any society and that, regardless of the religion chosen, are beneficial to learn. 
"Through religion basic values for social coexistence are taught. These values can also be taught using other channels like stories, films, the example itself. Religion is just one of them. If it is part of the schedule, it can be guaranteed that it will be worked in the classroom" (ex. Teacher 2).

Likewise, the teacher states that she has completed her training regarding this subject via distance learning courses.

\section{Teachers' experience regarding valued-based education in the classroom}

In relation to solving conflicts in the classroom, the teacher says that there are conflicts every day and that they are faced at the time based on mutual understanding, assertiveness and respect.

"If there is a conflict, it is resolved at the time through dialogue, working on empathy, respect and emotional expression" (ex. Teacher 9).

Concerning the planning of values-based education, there is no schedule or stablished timetable for mentoring and/or specific activities to work certain values and/or counter values, except those taught in Religion.

"There is no specific time. They are occasional activities using audio-visual material and roleplaying" (ex. Teacher 10).

To evaluate this type of learning, the teacher points out that she considers the personal progress of each child throughout the school year.

\section{Assessment and teacher training regarding media}

The teacher recognises that media transmit values and counter values that society progressively internalise due to the influence and significance that they have in routines and social habits. Accordingly, she considers that superficial values prevail, and that they arouse feelings of dissatisfaction in society due to the belief in unreachable and unrealistic ideals.

"Media transmit a short and long term ideal of effortless success and an impossible beauty model. This is done in a subliminal way, with stereotypes that are far from reality" (ex. Teacher 13)

Concerning the training received regarding media during the training and professional path, the teacher acknowledges that she has not received formal training.

\section{Conclusion}

It was the aim of this study to collect the view of a teacher and the students of Primary Education as key figures in the process of understanding and inclusion of media and values in contemporary society and, in particular, in this educational stage that is highly significant in the educational system.

Regarding the goals initially set, it is worth mentioning that during this process a positive perception of the understanding between social values and media from the view of the studied subjects was collected. However, in relation to the second goal referring to the assessment of needs and training deficiencies of students and teachers in values-based 
education (collected by the in-depth interview), students and teachers training deficiencies were observed. In this respect, it is to be noticed that learners ignore certain basic skills and strategies about cooperative work and peer relationships.

Moreover, within the framework of the communication media addressed in this study, considering the third goal about interests and preferences of students, the results obtained regarding children preference for audio-visual tools and operable elements significantly stands out. The preference for audio-visual media consumption increases during leisure time.

A conclusion reached after analysing the teacher's opinion is that there is a need for a media education that has a comprehensive and multidimensional approach within the educational sphere, which helps in the development of basic skills for a society immersed in a media and technological environment. A media education that overcomes the mistakes of traditional schools and that adapts to changes, considering the versatility and liquidity of social human nature. Therefore, it is unquestionable the necessity of guiding and motivating students with an increasingly heterogeneous profile, taking into account the inclusion of media and plurality of values in the classroom. Both are elements that should be reflected within the curriculum planning and, therefore, in the structure of educational systems always related to the improvement of teaching-learning processes, with a planned and substantiated pedagogical foundation.

Taking this evidence as reference, it is considered necessary that teachers make a greater effort to provide students with civic elements that favour the development of a moral, critical and constructive education regarding the media. Media are an eminently educational tool and are essential for developing a critical, analytical, systematic and reflexive mind in contemporary society (Nupairoj, 2016).

As regards the improvement-susceptible aspects throughout the interview and the questionnaire, it is a constant the need of improvement of a critical analysis concerning the underlying values in the media programmes that influence learners' cultural and educational acquisition patterns. In particular, the teacher consciously expresses the relevance of communication media in the development and interests of her students. However, due to ignorance, lack of information or lack of curriculum incorporation in the policy document of Primary Education (citar falta presencia curricular ramírez), a critical and in-depth analysis regarding this matter is needed.

Likewise, it is considered that for the future, it would be appropriate to conduct a study regarding values and media that includes families' vision as essential educational agents in this social and instructive duty. Furthermore, it would be positive to consider family training regarding media as a basic enclave for a synchronic education between family, society and school (Plaza and Caro, 2016; Nupairoj, 2016).

Finally, taking into account the previously mentioned vicissitudes, the results of the study must be considered with caution for many reasons; for instance, their limitation due to the size of the sample and the methodology used (participation of the most affected teacher, typical limitations of the questionnaire, etc.). Likewise, throught the speeches collected it is necessary to include the voice of the families and the management team, performing in future studies a triangulation between the thoughts of teachers, Primary Education students and of other educational agents that can help to offer a wider panorama of the reality of these studies. Nonetheless, it is understood that the results can be interesting fot the educational and scientific community since they offer an approach to teachers and students perception regarding values and media, as well as important information about 
the current status and limitations of educational centres than can and should be considered in future projects.

\section{Support and acknowledgements}

This paper was carried out thanks to the collaboration of Victoria Santana (Technical, Scientific and Literary Translator-English).

\section{References}

Aguaded Gómez J. I., Ferrés J., Cruz Díaz M., Pérez Rodríguez M.A., Sánchez Carrero J. and Delgado Ponce A., 2011. Informe de investigación: El grado de competencia mediática en la ciudadanía andaluza. Huelva: Comunicar.

Albizuri I.E., Samaniego C.M. and Torrientes, E.Q., 2001. Desarrollo de los valores en las instituciones educativas. Mensajero.

Ambrós, A. and Breu, R., 2007. Cine y Educación: El cine en el aula de Primaria y Secundaria. Barcelona: Graó.

Aparici R., Campuzano A., Ferrés J. and García A., 2010. La educación mediática en la escuela 2.0.

Besalú X., 2002. Un currículum intercultural. En X. Besalú, Diversidad cultural y educación, (pp. 73-114). Madrid: Síntesis.

Braslavsky C., 2004. Diez factores para una educación de calidad para todos en el siglo XXI. Madrid: Fundación Santillana.

Brighouse H., 2006. On education. Psychology Press.

Bringué X. and Sádaba Ch., 2009. La generación interactiva en España. Niños y adolescentes ante las pantallas. Madrid: Fundación telefónica.

Buxarrais M.R. and Martínez Martín M., 2009. "Educación en valores y educación emocional: propuestas para la acción pedagógica", Teoría de la Educación, Vol.10(2), pp. 263-275

Buxarrais R., 1997. La formación del profesorado en educación en valores: propuestas y materiales. Bilbao: Desclée de Brouwer.

Caldeiro M. C., 2014. Alfabetización comunicativa para el desarrollo de la autonomía moral: estudio de la competencia mediática en los adolescentes de Lugo (Galicia). (Tesis inédita de maestría, Universidad de Huelva).

Carr N., 2011. Qué está haciendo Internet con nuestras mentes? Superficiales. Madrid: Taurus.

Celot P. and Pérez Tornero J. M., 2009. Study on assessment criteria for media literacy levels. Retrieved from http://ec.europa.eu/culture/library/studies/literacy-criteria-report_en.pdf

Colectivo Eleuterio Quintanilla, 2000. Educación Intercultural: Por la diversidad cultural y la igualdad social.

Cuervo S.L., Medrano C. and Aierbe A., 2016. "Values perceived by adolescents on television: cross-cultural and gender differences", Educación XX1, Vol.19(2), pp.383-404.

Deval J., 2002. La escuela posible. Barcelona: Ariel.

Ferrés Prats J., 2007. "La competencia en comunicación audiovisual: dimensiones e indicadores", Comunicar, Vol.29, pp.100-107.

Fundación Marcelino Botín., 2004. "Banco de herramientas audiovisuals", In: Lázaro S. and Palomera R., Para la promoción de competencias personales y sociales, (pp.22-24). Santander: Pedrueca.

García Ruíz R., Ramírez A. and Rodríguez M.M., 2014. "Media literacy education for a new prosumer citizenship", Comunicar, Vol.22(43), pp.15-23.

Giner S., 1996. Carta sobre la democracia. Barcelona: Ariel.

Gómez de Benito J.L., 1996. "Psicología, cine y educación", Comunicar, Vol.7, pp.129-134 
González Fernández N., Sedeño M. and González Pérez V., 2012. "Diseño de un focus group para valorar la competencia mediática en escenarios familiares", Icono, Vol.14(3), pp.116-133.

Halstead J.M. and Taylor M.J., 1996. Values in education and education in values. Falmer Press.

Haydon G., 2003. Enseñar valores: un nuevo enfoque. Madrid: Morata.

Jiménez D.J., 2011. "El diario como un instrumento de autoformación e investigación", Revista Qurriculum, Vol.24, pp.173-200.

Jiménez J.R., 1997. "La educación en valores y los medios de comunicación", Comunicar, Vol.9, pp.15-22.

Martín A.G. and Tyner K., 2012. "Media literacy in multiple contexts", Comunicar, Vol.19(38), pp.10-12.

Martínez Martín, M., 2011. "Educación, valores y democracia", Revista de Educación, número extraordinario, pp.15-19.

Martínez Martín M., Esteban F. and Buxarrais M.R., 2011. "Escuela, profesorado y valores", Revista de Educación, número extraordinario, pp.95-113.

Martínez Martín M., Puig Rovira J.M. and Trilla J., 2009. "Escuela, profesorado y educación moral", Teoría educativa, Vol.15, pp.57-94.

Martínez L.A., 2007. La observación y el diario de campo en la definición de un tema de investigación. Perfiles Libertadores, Vol.4, pp.74-80.

Mínguez Vallejos R., 2014. "Ética de la vida familiar y transmisión de valores morales", Revista de educación, Vol.363. Retrieved from http://www.revistaeducacion.mec.es/doi/363_178.pdf

Nupairoj N., 2016. "El ecosistema de la alfabetización mediática: Un enfoque integral y sistemático para divulgar la educomunicación", Comunicar, Vol.24(49), pp.29-37.

Pérez Rodríguez M.A., Delgado A., García Ruíz R. and Caldeiro C., 2015. Niños y jóvenes ante las redes y pantallas. Barcelona: Gedisa.

Plaza J. and Caro C., 2016. "La implicación de la familia en la formación ético-cívica de los jóvenes a través de las TIC", Revista Aloma, Vol.34(2), pp.97-106

Quintana E.G., 2008. Técnicas e instrumentos de observación de clases y su aplicación en el desarrollo de proyectos de investigación reflexiva en el aula y de autoevaluación del proceso docente. In: Quintana E.G. (Ed.), La evaluación en el aprendizaje y la enseñanza del español como lengua extranjera/segunda lengua, pp.336-342.

Ramírez A., Renés P. and García M.R., 2014. "Presencia de la competencia mediática en los objetivos curriculares de la etapa educación Primaria", Teoría educativa, Vol.26(1), pp.137-159.

Savater F., 1997. El valor de educar. Barcelona: Ariel.

Sutrop M., 2015. "Can values be taught? The myth of value-free education", Trames: A Journal of the Humanities and Social Sciences, Vol.19(2), pp.189-202.

Tiede J. and Grafe S., 2016. "Pedagogía mediática en la formación de profesores de Alemania y EEUU", Comunicar, Vol.24(49), pp.19. https://doi.org/10.3916/C49-2016-02

Tucho F., 2008. "La educación en comunicación en la loe y sus decretos de Enseñanzas Mínimas", Comunicar, Vol.16(31), pp.547-553.

Tyner K., Gutiérrez Martín A. and Torrego A., 2015. "Multialfabetización sin muros en la era de la convergencia. La competencia digital y "la cultura del hacer" como revulsivos para una educación continua", Revista de curriculum y formación del profesorado, Vol.19(2), pp.41-56

UNESCO, 2015. Replantear la educación. Hacia un bien común mundial?

Valles M. S., 2002. "Entrevistas cualitativas", Cuadernos Metodológicos, Madrid: CIS (Colección Cuadernos Metodológicos, No.32) 